Article

\title{
Improving Design Performance by Alliance between Contractors and Designers in International Hydropower EPC Projects from the Perspective of Chinese Construction Companies
}

\author{
Qingzhen Zhang ${ }^{1}$, Wenzhe Tang ${ }^{1, *}$, Jersey Liu ${ }^{1}$, Colin F. Duffiel ${ }^{2}$, Felix Kin Peng Hui ${ }^{2}$, \\ Lihai Zhang ${ }^{2}$ (1) and Xuteng Zhang ${ }^{1}$ \\ 1 Department of Hydraulic Engineering, State Key Laboratory of Hydroscience and Engineering, \\ Tsinghua University, Beijing 100084, China; zqz15@mails.tsinghua.edu.cn (Q.Z.); \\ jersey.liu@foxmail.com (J.L.); zhangxut17@mails.tsinghua.edu.cn (X.Z.) \\ 2 Department of Infrastructure Engineering, The University of Melbourne, Melbourne, VIC 3010, Australia; \\ colinfd@unimelb.edu.au (C.F.D.); kin.hui@unimelb.edu.au (F.K.P.H.); lihzhang@unimelb.edu.au (L.Z.) \\ * Correspondence: twz@mail.tsinghua.edu.cn; Tel.: +86-10-6279-4324
}

Received: 19 March 2018; Accepted: 11 April 2018; Published: 13 April 2018

check for updates

\begin{abstract}
Extant literature lacks a systematic framework addressing the mechanisms of the alliance functional process and its impacts on management activities together with performance in delivering Engineering-procurement-construction (EPC) projects. This study quantitatively investigates the cause-effect relationships among these themes by building and validating a conceptual model of contractor-designer alliance in international hydropower EPC projects. With the support of data collected from an industry survey, the results reveal the key design problems, application of contractor-designer alliance, design management level and performance, which form a sound basis for design management emphasis in EPC activities, e.g., sufficiently considering sustainability of hydropower projects by incorporating environmental, social, and economic factors into designs. The path analysis indicates that the contractor-designer alliance can not only improve design performance by enhancing design management, but also directly promote design performance. This research has significant contributions to the body of knowledge by building interdisciplinary linkages between the areas of alliance, design management, and performance, theoretically demonstrating the mechanism of how interfirm cooperation functions to achieve superior design outcomes of hydropower EPC projects. Understanding these causal relationships will be crucial for contractors and designers to optimally allocate their complementary resources for seeking better design solutions in dealing with both technical issues and sustainability factors.
\end{abstract}

Keywords: hydropower; project management; engineering-procurement-construction; design management; design performance

\section{Introduction}

With the pressure of controlling climate change [1], hydropower, as a renewable energy, is a significant way to reduce greenhouse gas emissions, and the development of hydropower has become a trend for implementing the long-term strategy for sustainable energy worldwide, especially in developing countries of Asia, Africa, and Latin America [2-5]. For example, hydropower accounts for $99 \%$ and $85 \%$ of all electricity supply of Zambia and Brazil, respectively [6-8]. In developing countries, the engineering-procurement-construction (EPC) approach has been increasingly adopted to deliver hydropower projects by international contractors due to its high 
efficiency in integration of management of design, procurement, and construction activities [9]. Delivering international hydropower projects involves local markets, climate, ecological and environmental issues, transportation, economic and political circumstances, suppliers, local human resources, and impact on communities. An EPC contractor of an international hydropower project is responsible for fulfilling all project tasks of design, procurement, and construction $[10,11]$. However, few contractors are able to deliver hydropower EPC projects by only using their own expertise, and a large number of hydropower EPC contractors are construction companies with their strengths lying in construction [12,13]. As design governs procurement and construction activities, there is a clear need for these contractors to form alliances with the right designers for collaboratively achieving project objectives [14-18].

Interfirm alliance, as a type of relational governance, is a critical way to enhance value creation activities during project delivery [19]. Alliance arrangements are underpinned by incentive schemes specified in contracts, whereby the rewards of contractors and designers are directly linked to successful project performance [19-21]. Formal contracts and relational governance (e.g., alliance) function as complements [22,23], and contracts, trust, and relational norms jointly impact the performance [24]. Contractual governance alone is incapable of adaptation to systemic complexity [25], and alliance partners need to enhance their relational capabilities, e.g., establishing cooperation routines, exchanging information, and fostering interfirm trust [26]. Suitable alliances can help firms gain a sustainable competitive advantage by improving their absorptive capacity during inter-organizational cooperation $[16,27,28]$. High alliance performance largely depends on the competence of partners' combined capabilities in execution [29]. From a broad view, the improved capabilities of an alliance facilitate that the winning bid would be the one to have the best offer in the competitive marketplace, thereby improving the efficiency of industries [30].

Further studies demonstrated interfirm relational evolution, ranging from traditional relation, partnering to alliance [31], and classified alliance partners' linkages, including horizontal, vertical, and mixed interactions for problem resolution [14]. Appropriately selecting alliance partners and equitably allocating risks/rewards between them are also considered important [32]. An alliance should use clearly defined incentives to manage project activities [33], ensuring that the financial success of each partner relies on the success of the alliance [19].

However, previous studies typically focus on only one theoretical perspective [24] or remain at a prescriptive level with limited rigorous empirical evidence, and the impacts of the alliance functional process on project management and performance are unclear. Specifically, the extant literature lacks systematic framework addressing the mechanism by which performance improvements are actually generated from value creation activities of inter-organizational alliance. As relational governance is amenable to managerial control [23], failure to understand the quintessential nature of alliance would lead to a trial and error manner of management of project activities, as opposed to acting on an informed basis [31].

Thus, the aim of this research was to quantitatively reveal the causal relationships among contractor-designer alliance, design management, and design performance in international hydropower EPC projects by building and validating a conceptual model of contractor-designer alliance. In-depth understanding of the underlying factors that improve design performance will be crucial to integrate the resources of designers and contractors in delivering EPC projects. The specific research question is: How does alliance influence design management and design performance? To answer this question, we have systematically investigated the key aspects of international hydropower EPC project design activities, including the severity of the design problems, application of contractor-designer alliance, design management level, and design performance.

This study makes significant contributions to the relevant body of knowledge. Theoretically, this research has established a systematic framework revealing the mechanism as to the alliance functional process and its impacts on management activities together with performance. The insights from this research will help practitioners to optimally share their complementary resources for seeking better 
solutions in dealing with various hydropower project design problems related to technical, social, and environmental issues.

This paper is organized as follows. After the introduction, a conceptual model of contractordesigner alliance in international hydropower EPC projects is established. The following section details the research methodology. Then, the outcomes of survey analysis are presented. Furthermore, the path analysis is adopted to validate and interpret the relationships among alliance, design management, and design performance. Finally, the results of this study are given.

\section{Conceptual Model}

\subsection{Background}

International hydropower EPC projects are typically large and complex with many design challenges [15,34]. Extant studies on design problems in international hydropower EPC projects mainly regard: (1) causes of uncompetitive preliminary design in bidding, such as inadequate design information collection, technically uncompetitive design option, high construction cost of project, and unclear project scope [31,32]; (2) unfamiliarity with project-related standards or laws, especially for the differences in project standards or HSE laws at home and abroad [9,33]; (3) problems on design quality and time, e.g., design errors or defects, difficulty in obtaining approval from consulting engineers, design rework, and design delays [34,35]; (4) lack of incentives for promoting designs, mainly involving insufficient design optimization and low design fee causing inadequate design inputs [15]; (5) design-related interface management problems, including insufficient depth of design causing procurement delay, poor constructability of design option, inefficient coordination among EPC activities, ineffective communication with consulting engineers, poor management of design variation processes, and unstandardized information management of design [36].

Meeting with the above challenges requires EPC contractors to select suitable designers as their partners to form alliances with when dealing with various design problems [35,36]. Alliance facilitates contractors and designers to provide complementary resources to improve the design performance of hydropower EPC projects [31,37]. However, the interplay between of alliance, design management, and design performance are still unclear. This is attributed to the lack of a systematic framework addressing the mechanism by which performance improvements are actually generated from alliance partners' co-creating value in design management of EPC projects. Thus, a conceptual model of contractor-designer alliance has been established to help understand the causal relationships among contractor-designer alliance, design management, and design performance in delivering international hydropower EPC projects, as seen in Figure 1.

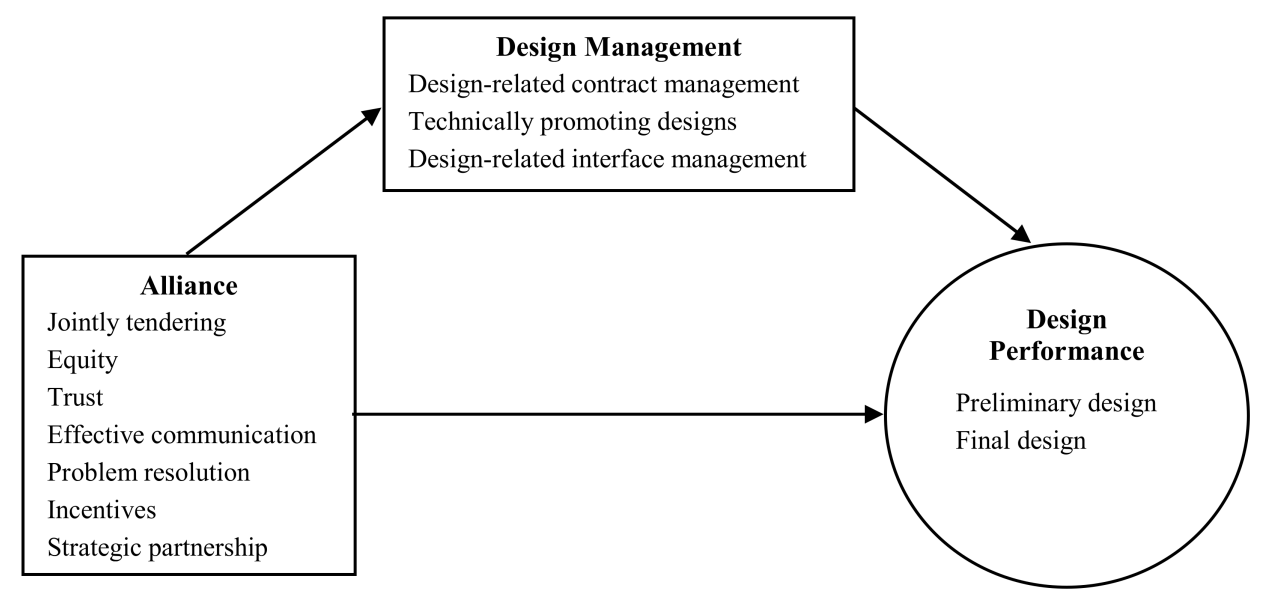

Figure 1. Conceptual model of contractor-designer alliance in international hydropower engineering-procurement-construction (EPC) projects. 


\subsection{Alliance}

Alliance, as a kind of relational governance, is a critical way to achieve a competitive advantage for the partners [38]. Parties in alliance contractually commit to their inputs and required rewards, and use an appropriate risk allocation, thereby aligning their objectives to manage the project activities [31]. The needs for adopting alliance can be attributed to two aspects. Firstly, contractual governance alone is incapable of adapting to complex systems [25], e.g., hydropower project development involving sophisticated engineering, social and environmental issues, and formal contracts and relational governance as factors that jointly impact the performance $[22,23,26]$. Secondly, alliance facilitates resource complementation among individual partners, and fosters their combined capabilities in achieving superior performance [16,27-29]. Studies of the critical components of alliance have been conducted by many researchers by identifying the key factors of alliance. The main key factors identified include jointly tendering, equity, trust, effective communication, problem resolution, incentives, and strategic partnership [15,28,29,37,39-41].

Nevertheless, existing research typically focuses on only one theoretical perspective [24], and there is a lack of coherent framework to address the interactions of the key alliance factors. Thus, this study has incorporated the above factors into an integrated framework of alliance functional process, as seen in Figure 2.

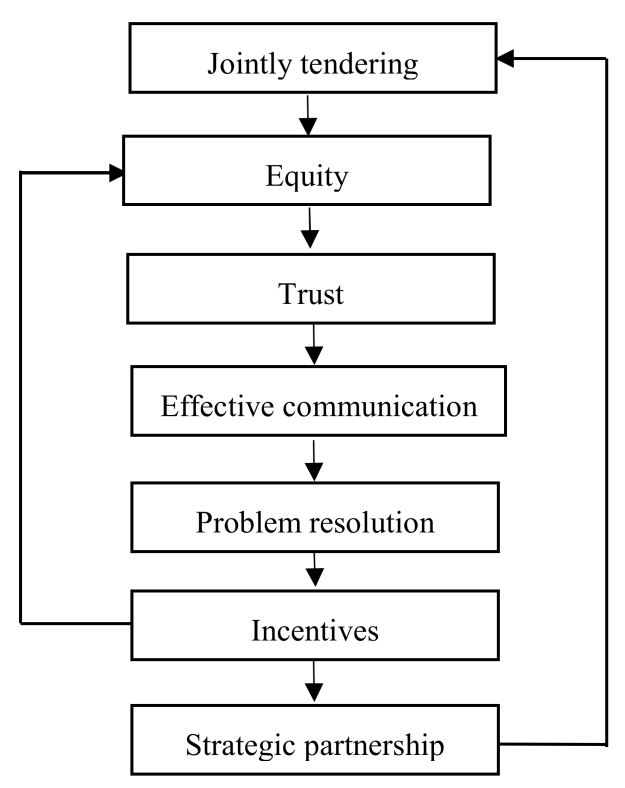

Figure 2. Alliance functional process in international hydropower EPC projects.

Alliance between contractors and designers starts with joint tendering at the bidding stage of international hydropower EPC projects [42]. The alliance appropriately identifying, classifying, and analyzing risks is critical for designers to fulfill satisfactory preliminary design as the basis of assigning risks in bidding documents [43]. Designers should not only be selected on the basis of their expertise to meet stringent design criteria, but also need to match the contractors' capabilities, such as their construction technology, human resources, and plans for preparing financially and technically competent bids $[28,44]$.

After successfully winning the bids, contractors and designers should equitably allocate rewards and risks during project implementation and foster a trust-based relationship with each other. By establishing trust, the boundaries of contractors and designers will gradually merge and become more permeable, allowing effective communication in collaboratively dealing with EPC activities [21,45-47]. Effective communication between contractors and designers assists necessary information to be appropriately integrated in design processes, which is critical to resolving complex problems such as 
meeting requirements of occupation health, safety, and environment (HSE), optimizing designs for cost saving, and improving constructability [48,49].

After successfully resolving design-related problems, incentive schemes should be executed to ensure that real equity between contractors and designers is achieved. Incentive schemes should be not only linked to design problem resolution processes but also tied with final hydropower EPC project outcomes, enabling designers to have strong motivations and necessary resources to achieve better design performance $[9,15,33,41]$. Successful delivery of hydropower EPC projects will form a sound basis for contractors and designers to establish long-term strategic partnerships, which facilitates joint tendering for future hydropower EPC projects to expand their international market share $[39,40]$.

\subsection{Design Management}

The design management in international hydropower EPC projects is not only closely related to whether the design performance meet clients' needs and requirements, but also whether it is able to create value by appropriately optimizing design options [50]. The design management approaches expressed in existing literature mainly involve design-related contract management, technically promoting designs, and design-related interface management [51-53].

Design-related contract management mainly includes design responsibility specification and claim management in hydropower EPC project delivery [34,54]. Design management of international hydropower EPC project starts from reviewing conceptual design for contractor-designer alliance to win EPC contracts [15]. Alliance can help contractors and designers to adequately consider the concerns of each other, and then appropriately decide the depth and responsibility of design in EPC contracts $[19,55]$. Nevertheless, EPC contracts will leave many uncertainties owing to some clients' requirements and needs being unable to be elaborated at the beginning of project implementation [56]. It is difficult to agree on whether clients' orders have changed the scope of work or not [57]. Unclear project definition in contracts prepared on the basis of conceptual design and clients' organizational behaviors, such as change orders, are main causes of claims in international hydropower EPC project delivery [34]. Timely process of claims caused by the implementation of owners' orders for variation should be an emphasis of design-related contract management of hydropower EPC projects [58].

Measures of technically promoting designs in international hydropower EPC project implementation include design quality assurance, internal review, external review, and using specific expertise as complements to designers. At the execution stage of EPC contracts, establishment of a design quality assurance system is essential to ensure various design departments to carry out their tasks [53]. The designs should not only incorporate clients' needs, meet requirements of occupation health, safety, and environment (HSE), and consider projects' effects on local communities, but also help to optimally achieve cost, time, and quality objectives on procurement and construction [59]. It is necessary for the contractor-designer alliance to establish internal and external design review processes for quality auditing, cost evaluation, construction schedule analysis, constructability analysis, and optimization of design options, thereby technically promoting designs [15]. However, sometimes the combined capability of alliance could be still insufficient for dealing with specific technical problems in international hydropower EPC projects [29]. It is necessary for the contractor-designer alliance to hire outstanding international or local consultancy firms, as complements to designers, for utilizing the firms' specific technical know-how to solve challenging design problems [9].

Indicators of design-related interface management are mainly related to integration management of EPC activities, coordinating design tasks, and design document management [51,60]. The high uncertainty nature of preliminary design in hydropower EPC projects implies that integrating design with procurement and construction is critical over the course of project delivery [61-63]. As design governs procurement and construction activities, coordinating various design departments to meet requirements of project schedule is also a key aspect of design-related interface management $[61,64]$. Standardized management of design-related documents between project participants reduces problems arising from miscommunication and incomplete information and improves processing efficiency of 
work flows in the implementation of EPC projects $[65,66]$. Contractor-designer alliance can improve design-related interface management and reduce problems arising from miscommunication and incomplete information throughout overlapping EPC phases [51,60].

\subsection{Design Performance}

On the basis of the above analysis, it is expected that contractor-designer alliance can help achieve higher hydropower EPC project design performance throughout the two phases of bidding and project implementation [42].

At the bidding stage, indicators of preliminary design performance include conceptual design review, sufficiency of data, technical feasibility, and financial viability of design option [16,54]. Trust and effective communication established in alliance can help contractors and designers to clearly understand the intents of the clients/consulting engineers by reviewing conceptual designs in tender documents, thereby efficiently preparing bidding documents [15]. Alliance can facilitate contractors and designers to cooperatively collect relevant information on site conditions, local markets, social status, and environmental requirements to ensure the sufficiency of data for preliminary design, which helps to reduce high uncertainties in conceptual design of hydropower EPC projects [9]. Considering project scope, characteristics, function, and construction tasks, the proposed preliminary design option should be not only technically feasible, but also financially viable due to the contractor-designer alliance taking the main risk of hydropower EPC project cost [44,67].

At the project implementation stage, final design performance in hydropower EPC projects mainly involves basic design, detailed design, and coordination of procurement and construction [68]. After winning EPC contracts, alliance can result in added design input to propose feasible technical solutions to fulfil the basic design tasks by effectively utilizing the resources of both the contractor and designer, and obtain timely approvals from the consulting engineers [57]. Contractors and designers forming an alliance facilitates effective coordination among EPC activities in final design process, which is critical to ensuring the depth and progress of the design satisfying the requirements of procurement and construction.

\subsection{Empirical Research Questions}

Previous studies collectively identify a variety of design problems in international hydropower EPC projects, involving uncompetitive bidding, project-related standards or laws, design quality and time, design optimization, and interface management [9,51,57,69]. It is expected that contractors and designers forming alliances can facilitate dealing with the above design problems, and specifically, contractor-designer alliance can improve hydropower EPC project design performance, and design management plays mediation role between them as established in the conceptual model (see Figure 1). To test these, there is a need to have an industry survey for answering the following empirical research question: How does alliance influence design management and design performance in international hydropower EPC projects?

To answer this question, a systematic investigation has been conducted to collect data on the key themes of international hydropower EPC project design activities, including the severity of the design problems, application of contractor-designer alliance, design management level, and design performance. The details on data collection are as follows.

\section{Research Methods}

\subsection{Data Collection via the Triangulated Approach}

As the triangulated method facilitates obtaining a deeper understanding of a research topic [70], this research used a triangulated approach for collecting both quantitative and qualitative data, including questionnaire, interview, and case data. 
Based on the above literature review, the questionnaire has been designed to collect data for validating the conceptual model (Figure 1), which was the main data collection instrument. A five-point Likert scale was adopted to evaluate international hydropower EPC project design problems, alliance, design management, and design performance in a quantitative manner. As Chinese contractors account for about $50 \%$ of market share in the global hydropower industry [34], we decided to collect data from Chinese construction companies who have delivered international hydropower EPC projects. To avoid the low response rate of postal surveys [71], four fieldtrips had been conducted to survey four Chinese construction companies (one trip to one firm). These four Chinese construction companies were chosen for surveying because the firms, as main contractors, have delivered a large number of international hydropower EPC projects that are scattered in Africa, Asia, South America, and Oceania, which is consistent with the share of Chinese contractors' international business. These construction companies normally select Chinese consulting companies as partnered designers, and their alliance starts from jointly tendering for international hydropower EPC projects.

The respondents from the four companies were initially identified and contacted through personal relationships, and then direct communication with them confirmed the survey arrangements for this study. Fieldtrip survey enabled all distributed questionnaires to be returned, and a total of 134 questionnaires have been collected. Excluding 32 invalid ones with incomplete information, 102 questionnaires were used for analysis. Fieldtrip surveys facilitate immediate semi-structured interviews with the respondents holding senior positions after finishing the questionnaire. The themes of questionnaire were used as the interview topics, enabling data collected from interviews to confirm and interpret the results from the questionnaires. Overall, 35 respondents were interviewed. The profiles of the respondents and interviewees are shown in Table 1.

Table 1. The profiles of the respondents and interviewees.

\begin{tabular}{|c|c|c|c|c|c|c|c|c|c|}
\hline \multirow[t]{2}{*}{$\begin{array}{l}\text { Roles of Respondents } \\
\text { /Interviewees }\end{array}$} & \multirow[t]{2}{*}{$\begin{array}{l}\text { Number of } \\
\text { Respondents } \\
\text { /Interviewees }\end{array}$} & \multicolumn{4}{|c|}{$\begin{array}{c}\text { Working Years of } \\
\text { Respondents/Interviewees }\end{array}$} & \multicolumn{4}{|c|}{$\begin{array}{l}\text { Distribution of Samples } \\
\text { (Respondents/Interviewees) }\end{array}$} \\
\hline & & $3-5$ & $6-10$ & $11-20$ & $>20$ & $\begin{array}{l}\text { Southeast and } \\
\text { South Asia }\end{array}$ & Africa & $\begin{array}{l}\text { Latin } \\
\text { America }\end{array}$ & Oceania \\
\hline CEOs/Deputy CEOs & $5 / 5$ & & & & $5 / 5$ & $1 / 1$ & $2 / 2$ & $1 / 1$ & $1 / 1$ \\
\hline Project managers & $16 / 10$ & & & $6 / 3$ & $10 / 7$ & $4 / 3$ & $6 / 4$ & $4 / 2$ & $2 / 1$ \\
\hline $\begin{array}{l}\text { Heads/Deputy heads of } \\
\text { project management } \\
\text { department }\end{array}$ & $46 / 20$ & $4 / 0$ & $23 / 6$ & $12 / 9$ & $7 / 5$ & $15 / 6$ & $19 / 9$ & $9 / 4$ & $3 / 1$ \\
\hline Engineers & $35 / 0$ & $5 / 0$ & $18 / 0$ & $7 / 0$ & $5 / 0$ & $10 / 0$ & $15 / 0$ & $7 / 0$ & $3 / 0$ \\
\hline Total & $102 / 35$ & $9 / 0$ & $41 / 6$ & $25 / 12$ & $27 / 17$ & $30 / 10$ & $42 / 15$ & $21 / 7$ & $9 / 3$ \\
\hline
\end{tabular}

The respondents of 102 questionnaires are classified as: 5 (CEOs/Deputy CEOs), 16 (Project managers), 46 (Heads/Deputy heads of project management department), and 35 (Engineers). Among the respondents, $91.2 \%$ have more than 6 working years. The respondents, who are engaged in managing design, procurement, construction, HSE, and contracting, have rich experience in delivering international hydropower EPC projects. Specifically, as key management staff of EPC contractors, the respondents' experiences are closely related to design activities. For example, they need to evaluate constructability of designs considering requirements of local HSE laws, review whether design option is technically and financially feasible, and ensure sufficient depth of design for meeting lead times of equipment manufacture and installation. The distribution of samples was: Southeast and South Asia (30), Africa (42), Latin America (21), and Oceania (9).

The interviewed respondents include 5 CEOs/deputy CEOs, 10 project managers, and 20 heads/deputy heads of project management department. Among the interviewees, $82.9 \%$ have more than 11 working years. Interviews revealed some of the specific experiences and lessons of hydropower EPC projects, which can also help to explain the questionnaire survey results. 
In addition, data of two cases were gathered by interviews and collection of project documents. The data of two cases were used to verify and illustrate the relationships established in the conceptual model. One case is the Nadarivatu Hydropower Project, comprising of a $41.5 \mathrm{~m}$ high dam and a power plant with a $44 \mathrm{MW}$ generator, located in the main Island of Fiji. The total investment of the project is approximately US $\$ 131$ million, and the project implementation duration was about 4 years. Another case is the Djiploho Hydropower Project, comprising of a $26 \mathrm{~m}$ high dam and a power plant with four 30 MW generators, located on the middle of Wele River near Djiploho in Equatorial Guinea. The total investment of the project is approximately US $\$ 257$ million, and the project implementation duration was about 3.5 years. Both projects were undertaken by Chinese construction companies with the EPC project delivery approach.

\subsection{Data Analysis Techniques}

The statistical package for social science (SPSS 21.0) was used to analyze the data collected from the questionnaire survey. The adopted statistical analysis techniques included estimating means of the sample, rank cases, path analysis, Pearson correlation analysis, typical analysis, and reliability test. Cronbach's $\alpha$ is used to test the internal consistency (reliability), and the hurdles are: $0.7 \leq \alpha \leq 0.8$ (acceptable), $0.8 \leq \alpha \leq 0.9$ (good), and $\alpha \geq 0.9$ (excellent) [72]. Estimating means of the sample and rank cases help one to understand the status of design problems, contractor-designer alliance, design management, and design performance. Pearson correlation analysis and typical analysis are conducted to test and explain functional process of alliance. As path analysis can aid in confirming a cause-and-effect relationships, it was adopted to verify the casual relationships among alliance, design management, and design performance arising from the conceptual model (see Figure 1). The significant hurdle of Pearson correlation analysis and path analysis is the usual level of 0.05 , with a level of 0.01 being highly significant. The triangulated approach of using these analysis techniques facilitates an in-depth understanding of the research themes, thereby revealing unique findings.

\section{Survey Analysis}

\subsection{Design Problems}

To investigate the design problems in international hydropower EPC projects, respondents were asked to rate the severity of the listed design problems using a five-point Likert scale where $1=\mathrm{a}$ negligible problem and $5=$ a significant problem. The results are shown in Table 2.

Results in Table 2 show that the 18 problems have moderate to high ratings ranging from 3.19 to 3.94, indicating all the design problems should not be neglected. These design problems can be classified into four groups:

\section{(1) Design Problems Related to Unfamiliarity with Project-Related Standards and Laws}

"Unfamiliarity with the differences in project standards at home and abroad" (1st) obtains the highest rating, and "unfamiliarity with the local HSE laws" (10th) is also considered as an important issue. This suggests that sufficiently understanding the project required standards and involved local laws is challenging to international hydropower EPC project designers. This can be attributed to foreign international hydropower project-related standards/laws potentially being substantially different from Chinese standards/laws, not only in specific requirements, but also in underlying philosophy (Lei et al., 2017). Interviews confirm that, as the experience of designers has primarily been accumulated from domestic hydropower projects that normally adopt home standards, the designers' biggest problem is the unfamiliarity with foreign standards, especially when the designers are new entrants in an international market. For example, the design work of Nadarivatu hydropower EPC project in Fiji required the use of Australian and New Zealand standards, which were new to a designer. The designer's unfamiliarity with the standards was closely related to "design errors or defects" (2nd), resulting in "designs are difficult to obtain approval from consulting engineers" (6th) at the early stage 
of project delivery. These design problems further led to "design rework" (7th) and "design delays" (4th), which significantly affected the implementation of the project, e.g., causing a project delay of one year.

\section{(2) Uncompetitive Preliminary Design in Bidding}

Preliminary design starts from reviewing conceptual design given by consulting engineers in the tender documents. As many conceptual designs of hydropower EPC projects only generally define clients' needs and expectations, leaving high uncertainties for bidding, it is a great challenge for designers to prepare satisfactory preliminary designs to win the contracts. The most common preliminary design problem in bidding is "inadequate design information collection" (5th). This problem arises from not only the lack of ascertaining the clarity of clients' requirements and sufficiency of tender documents, but also insufficient input during the collection of important data, such as project geological conditions, climate, ecological and environmental issues, transportation, economic and political circumstances, suppliers, local human resources, and affected communities. Insufficient site data can cause problems such as inappropriate treatment of geological conditions and unsuitable dealing with social and environmental issues, leading to "design option is technically uncompetitive" (13th). Interviewed project managers indicated that inadequate design data can also cause "high construction cost of design option" (8th) and "uncertainty of projects' specific scope and unclear parameters of equipment cause deviation in project cost" (12th), which result in proposed preliminary design option being economically uncompetitive. These findings explicitly illustrate how preparing hydropower EPC project bids with insufficient information reduces the chances of obtaining satisfactory design solutions in the tenders (Xia et al., 2013).

\section{(3) Design-Related Interface Management Problems}

"Insufficient depth of design causes delays in the preparation of procurement plans and equipment manufacture" (3rd) is the third highest ranked rating, indicating the criticality of effectively coordinating design and procurement. The interviewed hydropower project managers pointed out that the major equipment of international hydropower EPC projects are normally purchased from global markets, which need long lead times from preparing procurement plan, equipment manufacture, and transport to installation at site. Insufficient depth of design will significantly reduce the lead time of procurement, creating high pressure in equipment manufacture and installation.

"Poor constructability of design option" (9th), "coordination efficiency between design, procurement and construction is low" (11th), "communication with consulting engineers is inefficient" (15th), "poor management of design variation processes" (17th), and "information management of design is not standardized" (18th) are also design-related interface management problems. These problems are attributed to project participants' intentions and needs have not been efficiently conveyed to relevant parties and clearly understood by them. For instance, poor constructability of design options normally arises from the designers not having sufficiently incorporated contractors' feedback into the design process.

\section{(4) Lack of Incentives for Promoting Designs}

It is not surprising that "insufficient design optimization" (14th) is a problem in project implementation. Once contractors have won the hydropower EPC contracts, they will bear the project cost risk. Interviews show that contractors using incentives to motivate designers to optimize the basic and detailed designs is critical in reducing project costs and improve the profits. Nevertheless, "low design fee causes inadequate design inputs" (16th) is still a barrier to achieve design objectives, and results in designers have insufficient resources to conduct in-depth value analysis for promoting designs. 
Table 2. Assessment of Design Problem Severity.

\begin{tabular}{ccc}
\hline Problems & Rating & Rank \\
\hline Unfamiliarity with the differences in project standards at home and abroad & 3.94 & 1 \\
\hline Design errors or defects & 3.94 & 2 \\
\hline $\begin{array}{c}\text { Insufficient depth of design causes delays in the preparation of procurement } \\
\text { plans and equipment manufacture }\end{array}$ & 3.93 & 3 \\
\hline Design delays & 3.90 & 4 \\
\hline Inadequate design information collection & 3.89 & 5 \\
\hline Design rework & 3.82 & 6 \\
\hline High construction cost of design option & 3.81 & 7 \\
\hline Poor constructability of design option & 3.80 & 8 \\
\hline Unfamiliarity with the local HSE laws & 3.75 & 9 \\
\hline Coordination efficiency between design, procurement and construction is low & 3.74 & 10 \\
\hline Uncertainty of projects' specific scope and unclear parameters of equipment \\
cause deviation in project cost & 3.68 & 11 \\
\hline Design option is technically uncompetitive & 3.63 & 12 \\
\hline Insufficient design optimization & 3.61 & 13 \\
\hline Poor management of design variation process & 3.48 & 14 \\
\hline Anformation management of design is not standardized & 3.47 & 15 \\
\hline Average & 3.28 & 16 \\
\hline
\end{tabular}

\subsection{Alliance}

\subsubsection{Assessment of Key Alliance Indicators}

To understand the alliance relationship between contractors and designers, the respondents were asked to judge the extent to which the seven indicators of alliance were achieved in international hydropower EPC project delivery on a five-point Likert scale of $1-5$, where $1=$ the lowest degree to $5=$ the highest degree. The results are shown in Table 3.

Table 3. Relationship between contractors and designers.

\begin{tabular}{|c|c|c|c|}
\hline Factors & Descriptions & Rating & Rank \\
\hline Jointly tendering & $\begin{array}{l}\text { Jointly complete the preliminary design to successfully tender for the } \\
\text { project }\end{array}$ & 4.13 & 1 \\
\hline Trust & Formation of mutual trust & 4.09 & 2 \\
\hline Strategic partnership & $\begin{array}{c}\text { Formation of long-term strategic partnership in expansion to the } \\
\text { international market }\end{array}$ & 4.04 & 3 \\
\hline Problem resolution & Collaboratively resolve problems in a timely manner & 4.00 & 4 \\
\hline $\begin{array}{l}\text { Effective } \\
\text { communication }\end{array}$ & Effectiveness and efficiency in communication & 3.91 & 5 \\
\hline Equity & Equitable allocating rewards/risks & 3.84 & 6 \\
\hline Incentives & $\begin{array}{c}\text { Establishment of incentive mechanism to effectively promote design } \\
\text { optimization, reduce project cost, and improve constructability of } \\
\text { designed work }\end{array}$ & 3.70 & 7 \\
\hline Average & & 3.96 & \\
\hline
\end{tabular}


As shown in Table 3, "jointly tendering" (1st), "trust" (2nd), "strategic partnership" (3rd) and "problem resolution" (4th) obtain high ratings ranging from 4 to 4.13 , showing that these key factors of alliance between contractors and designers have been achieved at a considerably higher level. Interviews confirm that contractors and designers made efforts to jointly win the international hydropower EPC project contracts and collaboratively resolve problems in project implementation, and after successful project delivery, they tended to form long-term partnerships underpinned by the established trust to tender for new projects.

"Effective communication" (5th), a moderate rating, indicates that achieving effectiveness and efficiency in communication is not easy. This is in line with that severity of "insufficient depth of design causes delays in the preparation of procurement plans and equipment manufacture" which ranks third (see Table 2), due to the complexity of managing various interfaces in EPC project implementation.

"Equity" (6th) and "incentives" (7th) have the lowest ratings, suggesting that achieving real gain-share/pain-share is most difficult in alliance between contractors and designers in international hydropower EPC projects. At the beginning of their cooperation, parties need to clearly specify equitable allocation of rewards/risks, and during project execution, establish appropriate incentives to promote design optimization, reduce project cost, and improve the constructability of designed work. The interviewed hydropower project managers pointed out that the difficulties in allocating rewards/risks arose from the high uncertainty experienced at the early stage of EPC projects, and the difficulty of using incentives lay in how to ensure the incentives are effective. For instance, the set incentives may be inadequate in motivating designers for optimization. Due to the information asymmetry between designers and contractors, the measurement of the value of design optimization also poses some challenges when deciding the amount of rewards to give the designers.

\subsubsection{Correlations between the Key Factors of Alliance}

To reveal the relationships among the factors of alliance (see Table 3) and test alliance functional process (see Figure 2), a Pearson correlation analysis of the factors was conducted, with the results shown in Table 4.

Table 4. Correlations between the key factors of alliance.

\begin{tabular}{|c|c|c|c|c|c|c|c|}
\hline Factors & $\begin{array}{c}\text { Jointly } \\
\text { Tendering }\end{array}$ & Equity & Trust & $\begin{array}{l}\text { Effective } \\
\text { Commun. }\end{array}$ & $\begin{array}{c}\text { Problem } \\
\text { Resolution }\end{array}$ & Incentives & $\begin{array}{c}\text { Strategic } \\
\text { Partnership }\end{array}$ \\
\hline $\begin{array}{c}\text { Jointly } \\
\text { tendering }\end{array}$ & 1 & & & & & & \\
\hline \multirow[t]{2}{*}{ Equity } & $0.612^{* *}$ & 1 & & & & & \\
\hline & 0.000 & & & & & & \\
\hline \multirow[t]{2}{*}{ Trust } & $0.634^{* *}$ & $0.672 * *$ & 1 & & & & \\
\hline & 0.000 & 0.000 & & & & & \\
\hline $\begin{array}{l}\text { Effective } \\
\text { communication }\end{array}$ & $\begin{array}{c}0.626^{* *} \\
0.000\end{array}$ & $\begin{array}{c}0.495^{* *} \\
0.000\end{array}$ & $\begin{array}{c}0.672 \text { ** } \\
0.000\end{array}$ & 1 & & & \\
\hline $\begin{array}{l}\text { Problem } \\
\text { resolution }\end{array}$ & $\begin{array}{c}0.670 \text { ** } \\
0.000\end{array}$ & $\begin{array}{c}0.472 \text { ** } \\
0.000\end{array}$ & $\begin{array}{c}0.598^{* *} \\
0.000\end{array}$ & $\begin{array}{c}0.685^{* *} \\
0.000\end{array}$ & 1 & & \\
\hline \multirow[t]{2}{*}{ Incentives } & $0.526^{* *}$ & $0.475^{* *}$ & $0.501^{* *}$ & $0.557^{* *}$ & $0.521^{* *}$ & 1 & \\
\hline & 0.000 & 0.000 & 0.000 & 0.000 & 0.000 & & \\
\hline $\begin{array}{c}\text { Strategic } \\
\text { partnership }\end{array}$ & $\begin{array}{c}0.626^{* *} \\
0.000\end{array}$ & $\begin{array}{c}0.485^{* *} \\
0.000\end{array}$ & $\begin{array}{c}0.502 * * \\
0.000\end{array}$ & $\begin{array}{c}0.518^{* *} \\
0.000\end{array}$ & $\begin{array}{c}0.638^{* *} \\
0.000\end{array}$ & $\begin{array}{c}0.506^{* *} \\
0.000\end{array}$ & 1 \\
\hline
\end{tabular}

Note: ${ }^{* *}=$ correlation is significant at the 0.01 level (two-tailed).

As shown in Table 4, all seven key alliance factors of jointly tendering, equity, trust, effective communication, problem resolution, incentives, and strategic partnership are significantly correlated with each other at the 0.01 level. The correlations among the key alliance factors demonstrate that 
alliance achievements arise from the interactions of the above factors, confirming the relationships established in alliance functional process of Figure 2. Specifically, trust has high correlations with equity and effective communication $\left(r=0.672^{* *}\right)$, respectively, validating that trust is not only closely influenced by equitable allocation rewards/risks, but is also the basis of effective communication in project implementation (see Figure 2). The correlation between effective communication and problem resolution is the strongest $\left(r=0.685^{* *}\right)$, confirming that effective communication can significantly facilitate solving problems in a timely manner during EPC project delivery, as shown in Figure 2.

\subsubsection{The Typical Indexes of the Key Alliance Factors}

The high-level correlations between the key alliance factors demonstrate that a representative factor could be selected by typical analysis technique for interpreting the variance of alliance [72]. The typical indexes of the key alliance factors are calculated by using the correlation coefficients in Table 4 with the equation: $R_{k}^{2}=\left(\sum_{i=1}^{k-1} r_{i}^{2}+\sum_{i=k+1}^{m} r_{i}^{2}\right) /(m-1)$, where $m=7$ (the number of factors). For example, the typical index of jointly tendering $R_{1}^{2}$ calculated as: $R_{1}^{2}=\left(0.6122^{2}+0.6342^{2}+0.6262^{2}+\right.$ $\left.0.6702^{2}+0.5262^{2}+0.6262^{2}\right) /(7-1)=0.381$. The results of typical analysis are shown in Table 5.

Table 5. Typical indices of key alliance factors.

\begin{tabular}{ccccccc}
\hline $\begin{array}{c}\text { Jointly } \\
\text { Tendering }\end{array}$ & Equity & Trust & $\begin{array}{c}\text { Effective } \\
\text { Communication }\end{array}$ & $\begin{array}{c}\text { Problem } \\
\text { Resolution }\end{array}$ & Incentives & $\begin{array}{c}\text { Strategic } \\
\text { Partnership }\end{array}$ \\
\hline 0.381 & 0.292 & 0.361 & 0.356 & 0.363 & 0.265 & 0.302 \\
\hline
\end{tabular}

As shown in Table 5, the typical index of jointly tendering is the highest (0.381), which can be considered as the representative factor and generally reflects the variance of alliance. This is not surprising, as contractors and designers jointly winning hydropower EPC project contracts is the basis of in-depth collaboration involving subsequent key alliance factors in project implementation. Contractors and designers being able to repetitively succeed in joint tendering can also illustrate that the two parties have stable and high level of alliance in delivery of international hydropower EPC projects.

\subsection{Design Management}

To examine contractors' design management level, respondents were asked to judge contractors' design management level in international hydropower EPC project by responding using a five-point Likert scale ranging from 1 to 5 , where $1=$ very poor and $5=$ very good. The results are shown in Table 6 .

Results in Table 6 demonstrate that all the ratings of design management indicators are lower than 4, indicating that the level of design management has large room for improvement, especially regarding external review and using specific expertise as complements to designers. The above indicators of design management can be illustrated from the following three aspects:

(1) Design-related contract management

"Design responsibility specification" (1st) and "claim management" (2nd) obtain the top two ratings, indicating that contractors have a relatively high level in design-related contract management. These are largely attributed to the fact that contractor-designer alliance cannot only learn from organizational process asset of delivering past hydropower EPC projects, but also can directly quote conditions of contract for EPC-Turnkey Projects by Fédération Internationale des lngénieurs-Conseils (FIDIC) when dealing with disputes in project implementation. Interviews show that the frequency of claims in hydropower EPC projects was significantly less than that in traditional Design-Bid-Build (DBB) projects due to much more risks falling to EPC contractors. The interviewed project managers pointed out that hydropower EPC project claims were mainly related to owners' requests for changing project scope (e.g., adding new work) and the force majeure events, such as earthquake, flood, strike, and terrorism attack. 
(2) Technically promoting designs

"Internal review" (3rd) has the third highest rating, demonstrating that contractor-designer alliance has considerably formal internal design review processes. Interviews show that contractor-designer alliance largely relied on their own expertise to conduct quality audits, cost evaluations, construction schedule analysis, constructability analysis, and optimization of design options for technically promoting designs. However, "external review" (8th) and "using specific expertise as complements to designers" (9th) obtain the lowest ratings. These suggest that contractor-designer alliance has a large margin for improvement in seeking external expertise assistance to deal with difficult technical issues. The interviewed hydropower project managers indicated that selecting local consultancy firms with experience suitable in solving specific design problems can significantly reduce construction cost and time.

(3) Design-related interface management

Due to the overlapping phases of engineering, procurement, and construction in hydropower EPC projects, design-related interface management is essential in fulfilling concurrent designs and implementing project integration management. "Coordinating design tasks" (4th), "design document management" (5th), and "design quality assurance" (6th), moderate ratings, illustrate that design-related interface management is not an easy task. This is attributed to the fact that design-related interface management involves complexly reciprocal inter- and intra-organizational activities. For instance, design planning should consider the needs of equipment procurement and construction, requiring progressive elaborations from suppliers and contractors with the proceeding of project delivery. Carrying out design tasks (e.g., civil, mechanical, and electrical) also requires good coordination from the different design departments and can be considered the management of internal interfaces of designers. "Integration management" (7th) with the third lowest rating also supports the argument that effectively incorporating procurement and construction information into the design process is challenging for hydropower EPC project implementation. This is due to the complexity of managing a large number of interfaces between or among interacting parties.

Table 6. Assessment of design management.

\begin{tabular}{|c|c|c|c|}
\hline Indicators & Descriptions & Rating & Rank \\
\hline $\begin{array}{l}\text { Design responsibility } \\
\text { specification }\end{array}$ & Clearly identify the depth and responsibility of design in EPC contracts & 3.96 & 1 \\
\hline Claim management & $\begin{array}{c}\text { Timely process of claims caused by the implementation of owners' orders for } \\
\text { variation }\end{array}$ & 3.82 & 2 \\
\hline Internal review & $\begin{array}{l}\text { Establishment of internal design review processes for quality audit, cost } \\
\text { evaluation, construction schedule analysis, constructability analysis, and } \\
\text { optimization of design options }\end{array}$ & 3.76 & 3 \\
\hline $\begin{array}{l}\text { Coordinating design } \\
\text { tasks }\end{array}$ & $\begin{array}{l}\text { Coordinating various design departments to produce design schedule in } \\
\text { accordance with the needs of equipment procurement and construction }\end{array}$ & 3.73 & 4 \\
\hline $\begin{array}{l}\text { Design document } \\
\text { management }\end{array}$ & $\begin{array}{c}\text { Standardized management of design-related documents between project } \\
\text { participants }\end{array}$ & 3.68 & 5 \\
\hline $\begin{array}{l}\text { Design quality } \\
\text { assurance }\end{array}$ & $\begin{array}{c}\text { Establishment of design quality assurance system, which ensures various } \\
\text { design departments to carry out their tasks }\end{array}$ & 3.67 & 6 \\
\hline $\begin{array}{l}\text { Integration } \\
\text { management }\end{array}$ & $\begin{array}{l}\text { Effectively incorporating procurement and construction information into the } \\
\text { design process for project integration management }\end{array}$ & 3.63 & 7 \\
\hline External review & $\begin{array}{l}\text { Organizing external expert panel to review designers' documents, and help } \\
\text { designers interpret the feedbacks from clients or consulting engineers }\end{array}$ & 3.38 & 8 \\
\hline $\begin{array}{l}\text { Using specific expertise } \\
\text { as complements to } \\
\text { designers }\end{array}$ & $\begin{array}{l}\text { Hiring outstanding international or local consultancy firms, as complements } \\
\text { to designers, for utilizing the firms specific technical know-how to solve } \\
\text { challenging design problems }\end{array}$ & 3.05 & 9 \\
\hline Average & & 3.63 & \\
\hline
\end{tabular}




\subsection{Design Performance}

Respondents were asked to rate design performances regarding preliminary design and final design on a five-point Likert scale ranging from 1 to 5 , where $1=$ very poor performance and $5=$ very good performance. The results are shown in Table 7.

Table 7. Design Performance assessment of international hydropower EPC project.

\begin{tabular}{|c|c|c|c|c|c|c|}
\hline $\begin{array}{l}\text { Design } \\
\text { Stages }\end{array}$ & Indicators & Descriptions & Rating & Rank & $\begin{array}{l}\alpha \text { for } \\
\text { Group }\end{array}$ & $\begin{array}{c}\alpha \text { for } \\
\text { Overall }\end{array}$ \\
\hline \multirow[t]{4}{*}{$\begin{array}{l}\text { Preliminary } \\
\text { design }\end{array}$} & Technical feasibility & $\begin{array}{l}\text { Propose technically feasible preliminary } \\
\text { design based on project scope, } \\
\text { characteristic, function, and construction } \\
\text { tasks }\end{array}$ & 4.10 & 1 & 0.860 & 0.910 \\
\hline & $\begin{array}{l}\text { Conceptual design } \\
\text { review }\end{array}$ & $\begin{array}{l}\text { Clearly understand the intents of the } \\
\text { clients/consulting engineers by } \\
\text { reviewing conceptual designs in tender } \\
\text { documents }\end{array}$ & 4.08 & 2 & & \\
\hline & Financial viability & $\begin{array}{l}\text { Quotation of proposed design option is } \\
\text { financially viable }\end{array}$ & 4.02 & 3 & & \\
\hline & Sufficiency of data & Ensure the sufficiency of data for design & 4.00 & 4 & & \\
\hline \multirow[t]{4}{*}{ Final design } & $\begin{array}{l}\text { Coordination with } \\
\text { procurement and } \\
\text { construction }\end{array}$ & $\begin{array}{l}\text { Depth and progress of design satisfies } \\
\text { the requirements of procurement and } \\
\text { construction }\end{array}$ & 3.80 & 5 & 0.853 & \\
\hline & Basic design & $\begin{array}{l}\text { Propose feasible major technical } \\
\text { solutions to fulfil the basic design tasks, } \\
\text { and obtain timely approvals from the } \\
\text { consulting engineers }\end{array}$ & 3.76 & 6 & & \\
\hline & Detailed design & $\begin{array}{l}\text { Fulfil detailed design tasks by delivering } \\
\text { construction drawings and technical } \\
\text { specifications together with design } \\
\text { calculations, and obtain timely } \\
\text { approvals from the consulting engineers }\end{array}$ & 3.73 & 7 & & \\
\hline & Average & & 3.93 & & & \\
\hline
\end{tabular}

\subsubsection{Design Performance at the Tendering Phase}

As shown in Table 7, at the tendering phase, two indicators of the preliminary design including "technical feasibility" (1st) and "conceptual design review" (2nd) are given the highest ratings, indicating that designers together with contractors clearly understand the intents of the clients/consulting engineers, and are able to propose technically feasible preliminary designs. These can be attributed to designers having accumulated rich experience in designing a large amount of technically challenging projects in domestic markets. The other two indicators of the preliminary design including "sufficiency of data" (3rd) and "financial viability" (4th) have relatively lower ratings. These are ascribable to the collection of site data of international hydropower projects being time and resource consuming, and that the quotations of proposed designs need to be based on some assumptions in estimating project costs. For example, due to unfamiliarity with the Australia and New Zealand standards, the cost estimation of the power transmission and transformation works in the Nadarivatu hydropower EPC project at Fiji was much lower than the actual cost.

\subsubsection{Design Performance at the Execution Phase}

At the execution phase, all indicators of the final design including "coordination with procurement and construction" (5th), "basic design" (6th) and "detailed design" (7th) have much lower ratings than the indicators of preliminary design. This demonstrates that fulfilling the technically complex design tasks in international hydropower project implementation, which closely interact with procurement and construction activities, is challenging for designers. 


\section{Testing the Model}

To validate the relationships among alliance, design management, and design performance as established in the model (see Figure 1), path analysis has been conducted. The mean is the "best estimate" of the value of the population and is the most frequently used measure of central tendency in behavioral studies [9]. The mean of the 7 key alliance indicators, the mean of the 9 design management indicators, and the mean of the 7 design performance indicators are used as variables to calculate the relationships among them, with the results as shown in Table 8.

Table 8. Test of mediated relationships among conceptual model indicators.

\begin{tabular}{ccccccccc}
\hline Step & Predictors & Criteria & $\boldsymbol{R}$ & $\boldsymbol{R}^{\mathbf{2}}$ & $\boldsymbol{R}^{\mathbf{2}} \boldsymbol{a}$ & $\boldsymbol{F}$ & $\boldsymbol{\beta}$ & $\boldsymbol{t}$ \\
\hline 1 & A & DP & 0.481 & 0.231 & 0.223 & 30.039 & $0.494^{* *}$ & 5.481 \\
2 & A & DM & 0.614 & 0.376 & 0.370 & 60.372 & $0.687^{* *}$ & 7.770 \\
3 & A & DP & 0.576 & 0.332 & 0.319 & 24.630 & $0.240^{*}$ & 2.244 \\
& DM & & & & & & $0.370^{* *}$ & 3.874 \\
\hline
\end{tabular}

Note: $R_{a}^{2}=$ adjust $R^{2} ; \beta=$ standardized regression coefficient. Abbreviations: $\mathrm{A}=$ alliance; $\mathrm{DP}=$ design performance; $\mathrm{DM}=$ design management. ${ }^{* *} p<0.01 ;{ }^{*} p<0.05$.

The results of Table 8 show that: (1) the regression coefficient of design performance predicted by alliance is $0.494(p<0.01)$ with the amount of variance explained by alliance being $23.1 \%\left(R_{2}=0.231\right)$, at the significance level of 0.01 ; (2) the regression coefficient of design management predicted by alliance is $0.687(p<0.01)$ with the amount of variance explained by alliance being $37.60 \%\left(R_{2}=0.376\right)$, at the significance level of 0.01 ; and (3) the regression coefficients of design performance jointly predicted by alliance and design management are $0.240(p<0.05)$ and $0.370(p<0.01)$ with the amount of variance explained being $33.2 \%\left(R_{2}=0.332\right)$, meeting the significance hurdle of 0.05 , and the effect that alliance exerts on design performance has decreased from the original 0.494 to 0.240 . These results indicate a partial mediation, as alliance has less effect on design performance when design management is included in the regression model. Thus, the conceptual model is supported, as shown in Figure 3.

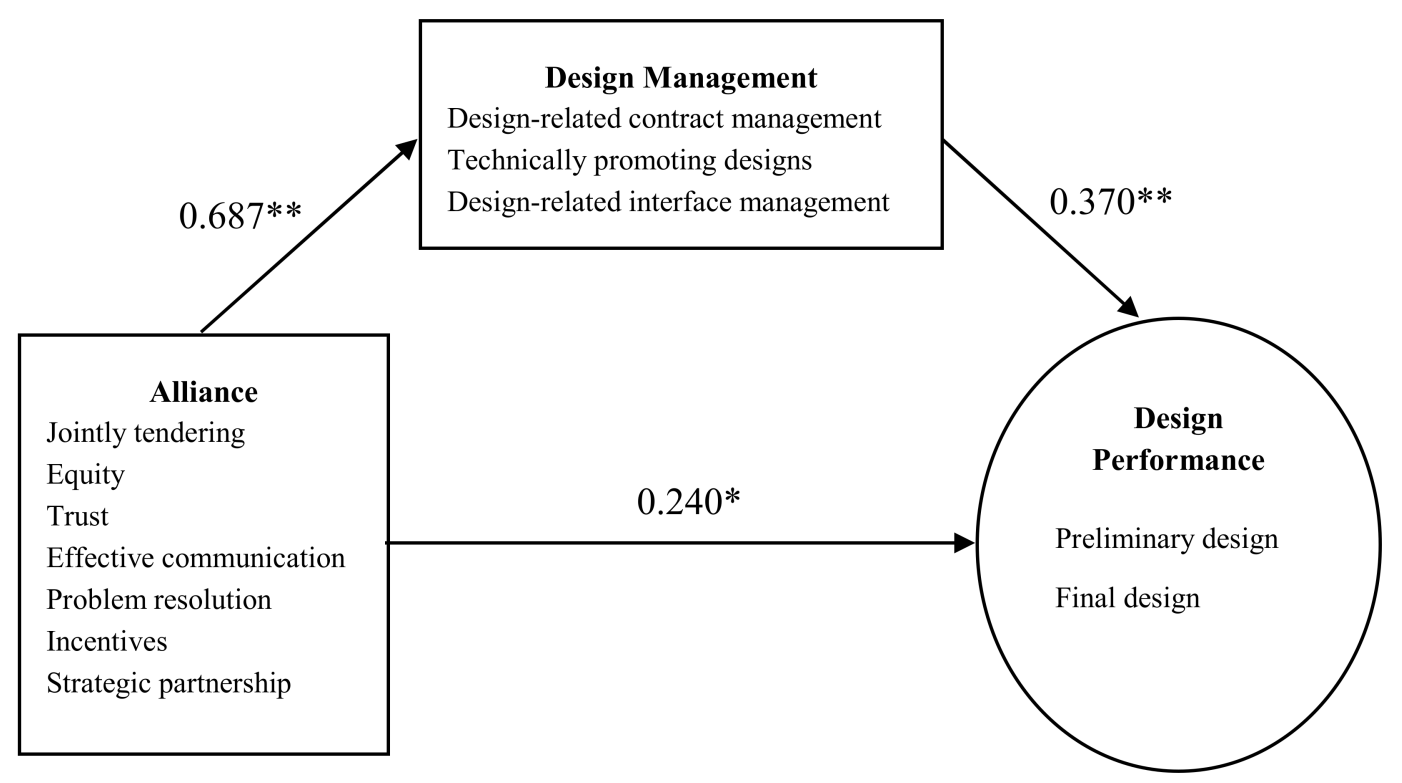

Figure 3. Relationships among alliance, design management, and design performance. Note: $* *=p<0.01{ }^{*}=p<0.05$.

The above results indicate two significant paths from alliance to design performance. One path is alliance $\rightarrow$ design management $\rightarrow$ design performance, and the other path is alliance $\rightarrow$ design 
performance. The results of path analysis confirm the mediation model (Figure 1), showing that the contractor-designer alliance can not only exert effect on design performance through enhancing design management, but also directly promote design performance. In general, the cause-effect relationships established in the conceptual model of alliance between contractors and designers in international hydropower EPC projects have been validated (see Figure 3), as interpreted below.

\subsection{Alliance and Design Management}

As shown in Figure 3, alliance is used to predict design management of international hydropower EPC projects, with the standardized regression coefficient being $0.687(p<0.01)$, confirming the strong influence of alliance on design management in international hydropower EPC projects. The roles of different key contractor-designer alliance factors in facilitating the design-related contract management, technical promotion of design, and design-related interface management are illustrated below.

Firstly, contractors and designers jointly tendering for international hydropower EPC projects can greatly facilitate design-related contract management. The two parties jointly completing preliminary design can help clearly identify the depth and responsibility of design in EPC contracts. This is because the preliminary design, based on conceptual design, needs the joint efforts of contractors and designers to collect a variety of data related to site conditions, environment, local economy, and affected communities for removing the high uncertainties in bidding. Interviews confirm that clear design responsibility specification is critical for solving the design problems such as "insufficient depth of design causes delays in the preparation of procurement plans and equipment manufacture" and "uncertainty of projects' specific scope and unclear parameters of equipment cause deviation in project cost", as seen in Table 2.

Secondly, emphasizing collaborative problem resolution in contractor-designer alliance can help tackle the key design issues for technically promoting designs. The key design issues can be identified in the internal design review process by means of quality audit, cost evaluation, construction schedule analysis, constructability analysis, and optimization of design options, and accordingly, contractors and designers could cooperatively find appropriate solutions to the design problems. As shown in the survey results (see Table 2), "designs are difficult to obtain approval from consulting engineers" is a key barrier to project implementation. This is largely attributed to designers' unfamiliarity with the project standards and local HSE laws. Interviews confirm that contractors organizing external expert panels with experience in similar projects to help interpret the feedback from consulting engineers is an effective inter-organizational learning approach, thereby assisting designers to meet requirements of the consulting engineers. It is also effective for contractors to hire outstanding international or local consultancy firms to complement the designers for utilizing the firms' specific technical know-how to solve challenging design problems. In this circumstance, the designers can allocate their resources to more efficiently fulfil the design tasks that are relevant to their technical strengths. As the price of EPC contract is fixed, use of incentives in contractor-designer alliance to promote design optimization is critical to ensure the project costs within the budget. The interviewed project managers confirmed that equitable sharing rewards from cost saving of design optimization can effectively motivate the designers to present value engineering proposals for solving problems of "low design fee causes inadequate design inputs", "insufficient design optimization", "high construction cost of design option" and "poor constructability of design option" as shown in Table 2.

Thirdly, trust-based effective communication in contractor-designer alliance is significant in enhancing design-related interface management. The concurrent design nature of EPC projects requires designers to not only coordinate various design departments (e.g., civil, mechanical, and electrical) to ensure the design quality, but also to efficiently incorporate procurement and site information into the design processes to meet the schedule needs of equipment manufacture and construction. An interviewed project manager of the hydropower EPC project in Djiploho pointed out that as the equipment needs a long time for manufacturing, delivery, and installation, insufficient depth of design or delay of drawings could result in high pressure on the contractors' coordinating procurement 
activities. Effective communication can assist contractors and designers to properly exchange the necessary information for reciprocal interdependent engineering, procurement, and construction processes, thereby helping to solve the problems such as "information management of design is not standardized", "coordination efficiency between design, procurement and construction is low", "inadequate design information collection", and "communication with consulting engineers is inefficient", as shown in Table 2.

\subsection{Design Management and Design Performance}

As shown in Figure 3, design management significantly predicts design performance with the standardized regression coefficient being $0.370(p<0.01)$, suggesting a close linkage between design management and design performance in international hydropower EPC projects. The details of how design management measures can enhance design performance is explained below.

Firstly, design-related contract management plays a critical role in governing the design deliverables at different stages. As EPC project designs are progressive, from reviewing the initial conception to final design, appropriate design management that clearly identifies the depth and responsibility of design in EPC contracts is critical to guide designers in fulfilling the tasks of preliminary design, basic design, and detailed design at different stages.

Secondly, technically promoting designs is significant to ensure design outcomes are both technically and financially feasible. The interviewed project managers indicated that contractors and designers mainly use their own expertise to audit design quality, estimate the cost of design options, and conduct constructability analysis for improving both preliminary and final design performance. Nevertheless, they pointed out that appropriate use of external expertise is indispensable in fulfilling design tasks of international hydropower EPC projects. For example, according to the Australia and New Zealand standards, the power transmission and transformation infrastructure, including transmission towers and transmission lines, in the Nadarivatu hydropower EPC project at Fiji must be able to resist a wind load of $90 \mathrm{~m} / \mathrm{s}$, which is much higher than the specified wind load of $38 \mathrm{~m} / \mathrm{s}$ in the Chinese technical standards. To solve the problem with the Chinese designer, who was unfamiliar with the Australia and New Zealand standards, a New Zealand consulting firm with relevant experience was hired to help successfully complete the detailed design of the project. This approach is effective in dealing with "unfamiliarity with the differences in project standards at home and abroad" that is ranked as the first design problem in international hydropower EPC projects (see Table 2).

Thirdly, design-related interface management is essential to coordinate design with procurement and construction. On one hand, effective interface management can help incorporating procurement and construction information into the design process, which ensures the sufficiency of data for high quality design, thereby reducing the design problems such as "inadequate design information collection", "design errors or defects", "design rework" and "insufficient design optimization" (see Table 2). Interviews confirm that many engineering proposals for design optimization arose from the valuable feedbacks from construction sites. On the other hand, efficient design-related interface management can ensure that the depth and progress of design satisfies the requirements of procurement and construction, and helps in avoiding the design problems of "insufficient depth of design causes delays in the preparation of procurement plans and equipment manufacture", "design delays", and "poor constructability of design option" (see Table 2).

Previous analysis has demonstrated the mediation role of design management in the control performance effect of alliance (see Figure 3). The key alliance factors, such as joint tendering, effective communication, and collaborative problem resolution, can greatly enhance design-related contract management, design-related interface management, and technically promoting designs, thereby improving preliminary design performance at bidding stage and final design outcomes in EPC project implementation. Besides, trust can also enhance design management by facilitating effective communication and problem resolution [73], and then improve design performance of international hydropower EPC projects. 


\subsection{Alliance and Design Performance}

As shown in Figure 3, alliance significantly predicts design performance with the standardized regression coefficients being $0.240(p<0.05)$, suggesting that, in addition to design management playing a partial mediation role between alliance and design performance, the contractor-designer alliance can also directly promote design performance. Alliance having a direct influence on design performance is attributed to that alliance factors such as joint tendering, equity, trust, effective communication, incentives, and strategic partnership help improve design performance by adding resources to the whole value-creation process of business $[13,33]$.

At the bidding stage, contractors and designers forming an alliance for jointly tendering on the basis of trust enables their organizational boundaries to be more permeable, and this allows the partners to input complementary resources to complete competent preliminary designing in international hydropower EPC projects. Interviews confirm that contractors' organizational process assets, such as the accumulated site data, the local market information, and the construction technology are valuable for designers to perform successful preliminary design. These illustrate that a basic goal of contractor-designer alliance is the creation of value by optimally using their combined resources [74].

At the project implementation stage, equally allocating rewards/risks in an alliance provides a sound basis for contractors and designers to work together, ensuring the basic and detailed designs not only meet the requirements of consulting engineers, but also are financially viable with building costs under budgets. Interviews show that use of incentives in the Djiploho hydropower project at Equatorial Guinea provided the designer with strong motivation and necessary resources to conduct value engineering analysis. For instance, the dam of the Djiploho project has been continuously optimized in both basic and detailed designs, which significantly reduced the construction cost and improved the constructability of the project. Application of incentives in a contractor-designer alliance can help solve the design problems of "insufficient design optimization" and "low design fee causes inadequate design inputs" (see Table 2) in delivering international hydropower EPC projects.

In the long term, contractors and designers forming strategic partnerships is effective in expansion to the international market, with the alliance combined capability increasing. For example, after the successful delivery of the Djiploho hydropower project, the contractor-designer alliance has won a series of bids of major hydropower projects, such as the Bata City electric network project and a reservoir project at upstream of the Djiploho hydropower project. This successful contractor-designer alliance illustrates the reduced learning curve and the increasing combined capability resulting from a long-term strategic partnership in international markets [52].

\section{Results and Discussions}

\subsection{Findings}

The EPC approach has been increasingly adopted to deliver international hydropower projects for implementing the long-term strategy on sustainable energy worldwide. In this study, the relationships among contractor-designer alliance, design management, and design performance of international hydropower EPC project demonstrated in the conceptual model have been tested and confirmed based on the perspective of Chinese hydropower construction contractors (see Figures 1 and 3). The major findings are as follows.

The survey results (see Table 2) reveal the key design problems in international hydropower EPC project delivery. The major problems in design mainly result from unfamiliarity with project involved standards and laws, uncompetitive preliminary design in bidding, poor design-related interface management, and lack of incentives for promoting designs.

All seven key alliance factors (i.e., jointly tendering, equity, trust, effective communication, problem resolution, incentives, and strategic partnership) are significantly correlated with each other (see Table 4). These significant correlations lead to the establishment of an alliance functional process (see Figure 2), in which alliance achievements arise from the interactions of these seven factors. 
Typical analysis shows that jointly tendering can be considered as the representative factor, which is because jointly winning EPC project contracts is the basis of in-depth collaboration between contractors and designers.

The survey results outline the status of design management and performance in international hydropower EPC projects. All the ratings of design management indicators are lower than 4 , indicating that the level of design management has large room for improvement, especially regarding external review and using specific expertise as complements to designers. The outcomes of design performance show that all indicators of the final design have much lower ratings than those of preliminary design. This indicates that it is challenging to fulfil the technically complex design tasks at the implementation stage of international hydropower EPC projects.

The path analysis indicates two significant pathways from contractor-designer alliance to design performance in international hydropower EPC projects (see Figure 3). One pathway is alliance $\rightarrow$ design management $\rightarrow$ design performance, and the other one is alliance $\rightarrow$ design performance. The results of pathway analysis confirm the conceptual model of alliance between contractors and designers in international hydropower EPC hydropower projects (see Figure 1), showing that the contractor-designer alliance can not only influence design performance through enhancing design management, but can also directly promote design performance.

Contractor-designer alliance can greatly facilitate design-related contract management on the basis of jointly tendering, help technically promoting designs by emphasizing collaborative problem resolution, and enhance design-related interface management with effective communication. Design management significantly predicting design performance is because design-related contract management largely governs the design deliverables; technically promoting designs is significant in ensuring design outcomes are technically and financially feasible; and design-related interface management is essential to coordinate EPC activities.

In addition to design management playing a partial mediation role between alliance and design performance, contractor-designer alliance can also directly enhance design performance. This means that key contractor-designer alliance factors such as trust, incentives and strategic partnership can provide the partners with strong motivation and necessary resources (e.g., partners inputting complementary resources into each other, and sharing rewards from project cost-saving) to achieve higher design performance by adding resources to the whole value-creation process of business.

The above findings imply broad practical strategies for improving international hydropower EPC project design performance. At the preliminary design stage, contractors and designers should not only understand the standards and laws required for project implementation, but also need to jointly collect a range of data related to site conditions, environment, local economy, and affected communities for managing the risks in bidding. This suggests that it is critical to sufficiently consider sustainability of hydropower projects by incorporating environmental, social, and economic factors into designs. At the final design stage, the contractor-designer alliance should use appropriate incentives to motivate technically promoting designs and to enhance management of interfaces among design, procurement, and construction.

\subsection{Discussions}

Extant literature lacks a systematic framework for addressing the mechanism of alliance functional process and its impacts on management activities together with performance, and existing studies largely remain at prescriptive level with limited rigorous empirical evidence support. By addressing the above-mentioned gaps, this study has made significant contributions to both theory and practice, as demonstrated below:

(1) This research established the conceptual model of contractor-designer alliance in international hydropower EPC projects, which theoretically demonstrated the interdisciplinary linkages among alliance, design management, and design performance from a holistic perspective. This theoretical contribution advanced the research outcomes on the complementary relationship 
between contractual and relational governance [22-26] and revealed the mechanism as to how improved performances are generated by optimally sharing partners' complementary resources and by fostering their combined capabilities.

(2) Existing research typically focuses on only one theoretical perspective [24], and there is a lack of a coherent framework to address the interactions of the key alliance factors, including jointly tendering, equity, trust, effective communication, problem resolution, incentives, and strategic partnership $[15,28,29,37,39-41]$. This study has incorporated the key factors into an integrated framework of alliance functional process and promoted the theoretical understanding of how alliance achievements can arise from the interactions of these factors. For instance, this study illustrated that strategic partnership is the outcome of interactions of the other alliance factors that were demonstrated in the framework, which can clearly explain the previous finding that relational length influences interplay between contractual and relational governance [24].

(3) With the support of data collected from the industry survey, this research validated the causal relationships built in the conceptual model, and specifically revealed that alliance can not only exert influence on the improvement of design performance by facilitating design management, but can also directly enhance design performance. This shows that design management plays a partial mediation role between alliance and design performance, and illustrates that, in addition to design management, partners' complementary resources and combined capabilities in alliance are also significant in adding value to design outcomes.

(4) The survey results have provided sound empirical evidence, and thereby revealed that the main design problems are related to the unfamiliarity with the standards and laws involved with the project, uncompetitive preliminary design in bidding, poor interface management, and lack of incentives. The results suggested that management should be emphasized to improve international hydropower EPC project design performance at both the bidding and project implementation stages.

(5) The above theoretical insights have significant practical implications and will help practitioners to optimally share their complementary resources in order to seek better solutions in dealing with various design problems. This is especially important for developing hydropower projects, as hydropower development involves a range of stakeholders who have specific interests in project outcomes. Appropriately incorporating social, economic, and environmental factors into the design of hydropower projects is critical in facilitating good public-private relationships, which is confirmed by the two cases in Fiji and Equatorial Guinea. From a broad view, the findings of this study can help to improve the integration management of hydropower development worldwide, especially for developing countries with a policy emphasis on the use of sustainable energy.

\subsection{Limitations and Future Research Directions}

The results of this research are based on the data collected from the Chinese contractors in the delivery of international hydropower EPC projects. Nevertheless, the findings of this study underpin global experience via literature, and they appear transferable to EPC projects worldwide. Future research is needed to test them by collecting data from other countries' contractors, on views of other EPC project participants (e.g., designers), and by using other causal modeling techniques such as structural equation modeling (SEM).

The insights of this study suggest that future research should emphasize design management in international EPC projects. Future research could be related to: (1) how contractors and designers could collaboratively reduce the high uncertainties of EPC projects in bidding by avoiding insufficient design data and the problems related to unfamiliarity with project involved standards or laws; (2) how to enhance EPC project interface management to ensure depth and progress of design satisfying the requirements of procurement and construction; and (3) how contractor-designer alliances use 
incentives to technically promote designs in one specific project, and to form a strategic partnership for achieving a long-term market expansion.

Acknowledgments: Many thanks are offered to the National Natural Science Foundation of China (Grant Nos. 51379104, 51579135, 51079070), and State Key Laboratory of Hydroscience and Engineering (Grant Nos. 2013-KY-5, 2015-KY-5). Major Science and Technology Research Project of Power China (Grant Nos. DJ-ZDZX-2015-01-02, DJ-ZDZX-2015-01-07).

Author Contributions: Qingzhen Zhang and Wenzhe Tang collaboratively conceived the study, and wrote the paper. Colin F. Duffiel, Felix Kin Peng Hui and Lihai Zhang contributed to analysis and discuss. Jersey Liu and Xuteng Zhang assisted in the data collection. All the authors read carefully and approved the final version of the manuscript.

Conflicts of Interest: The authors declare no conflict of interest.

\section{References}

1. Jager-Waldau, A. Snapshot of photovoltaics-march 2017. Sustainability 2017, 9, 783. [CrossRef]

2. Tang, W.Y.; Li, Z.M.; Tu, Y. Sustainability risk evaluation for large-scale hydropower projects with hybrid uncertainty. Sustainability 2018, 10, 138. [CrossRef]

3. Tang, W.Z.; Li, Z.Y.; Qiang, M.S.; Wang, S.L.; Lu, Y.M. Risk management of hydropower development in China. Energy 2013, 60, 316-324. [CrossRef]

4. Liang, X.D.; Si, D.Y.; Xu, J. Quantitative evaluation of the sustainable development capacity of hydropower in China based on information entropy. Sustainability 2018, 10, 529. [CrossRef]

5. He, L.; Li, C.L.; Nie, Q.Y.; Men, Y.; Shao, H.; Zhu, J. Core abilities evaluation index system exploration and empirical study on distributed PV-generation projects. Energies 2017, 10, 2083. [CrossRef]

6. Tembo, B.; Merven, B. Policy options for the sustainable development of Zambia's electricity sector. J. Energy S. Afr. 2013, 24, 16-27.

7. Soito, J.L.D.; Freitas, M.A.V. Amazon and the expansion of hydropower in Brazil: Vulnerability, impacts and possibilities for adaptation to global climate change. Renew. Sust. Energy Rev. 2011, 15, 3165-3177. [CrossRef]

8. Kahn, J.R.; Freitas, C.E.; Petrere, M. False shades of green: The case of Brazilian Amazonian hydropower. Energies 2014, 7, 6063-6082. [CrossRef]

9. Du, L.; Tang, W.Z.; Liu, C.N.; Wang, S.L.; Wang, T.F.; Shen, W.X.; Huang, M.; Zhou, Y.Z. Enhancing engineer-procure-construct project performance by partnering in international markets: Perspective from Chinese construction companies. Int. J. Proj. Manag. 2016, 34, 30-43. [CrossRef]

10. Micheli, G.J.L.; Cagno, E. The role of procurement in performance deviation recovery in large EPC projects. Int. J. Eng. Bus. Manag. 2016, 8, 1-17. [CrossRef]

11. Chan, A.P.C.; Scott, D.; Lam, E.W.M. Framework of success criteria for design/build projects. J. Manag. Eng. 2002, 18, 120-128. [CrossRef]

12. AlMaian, R.Y.; Needy, K.L.; Walsh, K.D.; Alves, T.D.L. A qualitative data analysis for supplier quality-management practices for engineer-procure-construct projects. J. Constr. Eng. Manag. 2016, 142. [CrossRef]

13. Pal, R.; Wang, P.; Liang, X.P. The critical factors in managing relationships in international engineering, procurement, and construction (IEPC) projects of Chinese organizations. Int. J. Proj. Manag. 2017, 35, 1225-1237. [CrossRef]

14. Chiambaretto, P.; Fernandez, A.S. The evolution of coopetitive and collaborative alliances in an alliance portfolio: The Air France case. Ind. Market. Manag. 2016, 57, 75-85. [CrossRef]

15. Wang, T.F.; Tang, W.Z.; Qi, D.S.; Shen, W.X.; Huang, M. Enhancing design management by partnering in delivery of international EPC projects: Evidence from Chinese construction companies. J. Constr. Eng. Manag. 2016, 142. [CrossRef]

16. Ge, H.F.; Chen, S.L.; Chen, Y.J. International alliance of green hotels to reach sustainable competitive advantages. Sustainability 2018, 10, 573. [CrossRef]

17. Liu, A.J.; Liu, H.Y.; Xiao, Y.X.; Tsai, S.B.; Lu, H. An empirical study on design partner selection in green product collaboration design. Sustainability 2018, 10, 133. [CrossRef]

18. Walker, D.; Lloyd-Walker, B. Understanding collaboration in integrated forms of project delivery by taking a risk-uncertainty based perspective. Adm. Sci. 2016, 6. [CrossRef] 
19. Hauck, A.J.; Walker, D.H.T.; Hampson, K.D.; Peters, R.J. Project alliancing at national museum of Australia-Collaborative process. J. Constr. Eng. Manag. 2004, 130, 143-152. [CrossRef]

20. Lloyd-Walker, B.; Walker, D. Authentic leadership for 21st century project delivery. Int. J. Proj. Manag. 2011, 29, 383-395. [CrossRef]

21. Anvuur, A.M.; Kumaraswamy, M.M. Conceptual model of partnering and alliancing. J. Constr. Eng. Manag. 2007, 133, 225-234. [CrossRef]

22. Poppo, L.; Zenger, T. Do formal contracts and relational governance function as substitutes or complements? Strat. Manag. J. 2002, 23, 707-725. [CrossRef]

23. Zheng, J.; Roehrich, J.K.; Lewis, M.A. The dynamics of contractual and relational governance: Evidence from long-term public-private procurement arrangements. J. Purch. Supply Manag. 2008, 14, 43-54. [CrossRef]

24. Cao, Z.; Lumineau, F. Revisiting the interplay between contractual and relational governance: A qualitative and meta-analytic investigation. J. Oper. Manag. 2015, 33-34, 15-42. [CrossRef]

25. Roehrich, J.; Lewis, M. Procuring complex performance: Implications for exchange governance complexity. Int. J. Oper. Prod. Manag. 2014, 34, 221-241. [CrossRef]

26. Kreye, M.E.; Roehrich, J.K.; Lewis, M.A. Servitising manufacturers: The impact of service complexity and contractual and relational capabilities. Prod. Plan. Control 2015, 26, 1233-1246. [CrossRef]

27. Yoon, C.; Lee, K.; Yoon, B.; Toulan, O. Typology and success factors of collaboration for sustainable growth in the it service industry. Sustainability 2017, 9, 2017. [CrossRef]

28. Chen, H.H.; Lee, A.H.I.; Xing, X.Q.; Chen, H. The relationships of different modes of international alliance with performance of renewable energy enterprises. Renew. Energy 2014, 69, 464-472. [CrossRef]

29. Wang, Y.Z.; Rajagopalan, N. Alliance capabilities: Review and research agenda. J. Manag. 2015, 41, $236-260$. [CrossRef]

30. Marques, R.C.; Berg, S. Public-private partnership contracts: A tale of two cities with different contractual arrangements. Public Adm. 2011, 89, 1585-1603. [CrossRef]

31. Tang, W.Z.; Duffield, C.F.; Young, D.M. Partnering mechanism in construction: An empirical study on the Chinese construction industry. J. Constr. Eng. Manag. 2006, 132, 217-229. [CrossRef]

32. Palacios, J.L.; Gonzalez, V.; Alarcon, L.F. Selection of third-party relationships in construction. J. Constr. Eng. Manag. 2014, 140. [CrossRef]

33. Tang, W.H.; Qiang, M.S.; Duffield, C.F.; Young, D.M.; Lu, Y.M. Incentives in the Chinese construction industry. J. Constr. Eng. Manag. 2008, 134, 457-467. [CrossRef]

34. Shen, W.X.; Tang, W.Z.; Yu, W.Y.; Duffield, C.F.; Hui, F.K.P.; Wei, Y.P.; Fang, J. Causes of contractors' claims in international engineering-procurement-construction projects. J. Civ. Eng. Manag. 2017, 23, 727-739. [CrossRef]

35. Love, P.E.D.; Lopez, R.; Kim, J.T.; Kim, M.J. Probabilistic assessment of design error costs. J. Perform. Constr. Facil. 2014, 28, 518-527. [CrossRef]

36. Arditi, D.; Elhassan, A.; Toklu, Y.C. Closure to "Constructability analysis in the design firm" by David Arditi, Ahmed Elhassan, and Y. Cengiz Toklu. J. Constr. Eng. Manag. 2004, 130, 302-304. [CrossRef]

37. Johnson, T.R.; Feng, P.; Sitzabee, W.; Jernigan, M. Federal acquisition regulation applied to alliancing contract practices. J. Constr. Eng. Manag. 2013, 139, 480-487. [CrossRef]

38. Das, T.K.; Teng, B.S. A resource-based theory of strategic alliances. J. Manag. 2000, 26, 31-61. [CrossRef]

39. Love, P.E.D.; Mistry, D.; Davis, P.R. Price competitive alliance projects: Identification of success factors for public clients. J. Constr. Eng. Manag. 2010, 136, 947-956. [CrossRef]

40. Judge, W.Q.; Dooley, R. Strategic alliance outcomes: A transaction-cost economics perspective. Br. J. Manag. 2006, 17, 23-37. [CrossRef]

41. Rowlinson, S.; Cheung, F.Y.K.; Simons, R.; Rafferty, A. Alliancing in Australia-no-litigation contracts: A tautology? J. Prof. Issue Eng. Educ. Pract. 2006, 132, 77-81. [CrossRef]

42. Wang, T.F.; Tang, W.Z.; Du, L.; Duffield, C.F.; Wei, Y.P. Relationships among risk management, partnering, and contractor capability in international EPC project delivery. J. Manag. Eng. 2016, 32. [CrossRef]

43. Marques, R.C.; Berg, S. Risks, Contracts, and private-sector participation in infrastructure. J. Constr. Eng. Manag. 2011, 137, 925-932. [CrossRef]

44. Vashani, H.; Sullivan, J.; El Asmar, M. DB 2020: Analyzing and forecasting design-build market trends. J. Constr. Eng. Manag. 2016, 142. [CrossRef]

45. Crowley, L.G.; Karim, A. Conceptual-model of partnering. J. Manag. Eng. 1995, 11, 33-39. [CrossRef] 
46. Rahman, M.M.; Kumaraswamy, M.M. Contracting relationship trends and transitions. J. Manag. Eng. 2004, 20, 147-161. [CrossRef]

47. Kumaraswamy, M.M.; Ling, F.Y.Y.; Rahman, M.M.; Phng, S.T. Constructing relationally integrated teams. J. Constr. Eng. Manag. 2005, 131, 1076-1086. [CrossRef]

48. Pulaski, M.H.; Horman, M.J. Organizing constructability knowledge for design. J. Constr. Eng. Manag. 2005, 131, 911-919. [CrossRef]

49. Grau, D.; Back, W.E.; Prince, J.R. Benefits of on-site design to project performance measures. J. Manag. Eng. 2012, 28, 232-242. [CrossRef]

50. Liu, C.Y.; Tong, L.I. Developing automatic form and design system using integrated grey relational analysis and affective engineering. Appl. Sci. 2018, 8. [CrossRef]

51. Shen, W.X.; Tang, W.Z.; Wang, S.L.; Duffield, C.F.; Hui, F.K.P.; You, R.C. Enhancing trust-based interface management in international engineering-procurement-construction projects. J. Constr. Eng. Manag. 2017, 143. [CrossRef]

52. Song, L.G.; Mohamed, Y.; AbouRizk, S.M. Early contractor involvement in design and its impact on construction schedule performance. J. Manag. Eng. 2009, 25, 12-20. [CrossRef]

53. Ezeldin, A.S.; Abu-Ghazala, H. Quality management system for design consultants: Development and application on projects in the Middle East. J. Manag. Eng. 2007, 23, 75-87. [CrossRef]

54. Gransberg, D.D.; Windel, E. Communicating design quality requirements for public sector design/build projects. J. Manag. Eng. 2008, 24, 105-110. [CrossRef]

55. Franz, B.; Leicht, R.; Molenaar, K.; Messner, J. Impact of team integration and group cohesion on project delivery performance. J. Constr. Eng. Manag. 2017, 143. [CrossRef]

56. Love, P.E.D.; Edwards, D.J.; Irani, Z.; Goh, Y.M. Dynamics of rework in complex offshore hydrocarbon projects. J. Constr. Eng. Manag. 2011, 137, 1060-1070. [CrossRef]

57. Xia, B.; Molenaar, K.; Chan, A.; Skitmore, M.; Zuo, J. Determining optimal proportion of design in design-build request for proposals. J. Constr. Eng. Manag. 2013, 139, 620-627. [CrossRef]

58. Klanac, G.P.; Nelson, E.L. Trends in construction lost productivity claims. J. Prof. Issue Eng. Educ. Pract. 2004, 130, 226-236. [CrossRef]

59. Lopez, R.; Love, P.E.D. Design error costs in construction projects. J. Constr. Eng. Manag. 2012, 138, 585-593. [CrossRef]

60. Chang, A.S.; Shen, F.Y.; Ibbs, W. Design and construction coordination problems and planning for design-build project new users. Can. J. Civ. Eng. 2010, 37, 1525-1534. [CrossRef]

61. Weshah, N.; El Ghandour, W.; Jergeas, G.; Falls, L.C. Factor analysis of the interface management (IM) problems for construction projects in Alberta. Can. J. Civ. Eng. 2013, 40, 848-860. [CrossRef]

62. Siao, F.C.; Lin, Y.C. Enhancing construction interface management using multilevel interface matrix approach. J. Civ. Eng. Manag. 2012, 18, 133-144. [CrossRef]

63. AL Mousli, M.H.; El-Sayegh, S.M. Assessment of the design-construction interface problems in the UAE. Archit. Eng. Des. Manag. 2016, 12, 353-366. [CrossRef]

64. Chen, Q.; Reichard, G.; Beliveau, Y. Multiperspective approach to exploring comprehensive cause factors for interface issues. J. Constr. Eng. Manag. 2008, 134, 432-441. [CrossRef]

65. Lin, Y.C. Construction network-based interface management system. Automat. Constr. 2013, 30, $228-241$. [CrossRef]

66. Chen, Q.; Reichard, G.; Beliveau, Y. Object model framework for interface modeling and it-oriented interface management. J. Constr. Eng. Manag. 2010, 136, 187-198. [CrossRef]

67. El Asmar, M.; Hanna, A.S.; Loh, W.Y. Quantifying performance for the integrated project delivery system as compared to established delivery systems. J. Constr. Eng. Manag. 2013, 139. [CrossRef]

68. Ke, H.; Cui, Z.P.; Govindan, K.; Zavadskas, E.K. The impact of contractual governance and trust on epc projects in construction supply chain performance. Inz. Ekon. 2015, 26, 349-363. [CrossRef]

69. Lei, Z.; Tang, W.Z.; Duffield, C.; Zhang, L.H.; Hui, F.K.P. The impact of technical standards on international project performance: Chinese contractors' experience. Int. J. Proj. Manag. 2017, 35, 1597-1607. [CrossRef]

70. Tang, W.Z.; Qiang, M.S.; Duffield, C.F.; Young, D.M.; Lu, Y.M. Risk management in the Chinese construction industry. J. Constr. Eng. Manag. 2007, 133, 944-956. [CrossRef]

71. Akintola, S.A.; MacLeod, J.M. Risk analysis and management in construction. Int. J. Proj. Manag. 1997, 15, 31-38. [CrossRef] 
72. Wang, S.L.; Tang, W.Z.; Li, Y.X. Relationship between owners' capabilities and project performance on development of hydropower projects in China. J. Constr. Eng. Manag. 2013, 139, 1168-1178. [CrossRef]

73. Wu, G.D.; Zhao, X.B.; Zuo, J. Relationship between project's added value and the trust-conflict interaction among project teams. J. Manag. Eng. 2017, 33. [CrossRef]

74. Harper, D.G.; Bernold, L.E. Success of supplier alliances for capital projects. J. Constr. Eng. Manag. 2005, 131, 979-985. [CrossRef] 